\title{
University-Community Engagement: Current Tensions and Future Trends
}

\author{
Olajumoke F. Ogunsanya and Ivan G. Govender
}

\begin{abstract}
Community engagement has become a key pillar of Higher Education that is intricately linked to the traditional academic roles of teaching and research. Meaningful collaboration with relevant external stakeholders that addresses critical socio-economic and developmental challenges in society is of strategic interest to many Higher Education Institutions. However, building significant and sustainable relationships between universities and external stakeholders is a complex task that is fraught with tensions that impede the achievement of set goals. A desktop documentary analysis was conducted using a literature review to examine these tensions with the objective of shedding light on how they impede institutionalisation of community engagement within universities. The article also identifies likely future trends in community engagement in the Higher Education sector, with particular emphasis on the impact of technology.
\end{abstract}

Key words: community engagement, higher education, universitycommunity engagement, community partnership, community-engaged scholarship, monitoring and evaluation

L'engagement communautaire est devenu un pilier central de l'Enseignement Supérieur qui est intrinsèquement lié aux rôles académiques traditionnels d'enseignement et de recherche. Une collaboration riche de sens avec des acteurs externes pertinents, qui se concentre sur les défis socio-économiques et développementaux critiques dans la société représente un intérêt stratégique pour beaucoup d'institutions d'Enseignement Supérieur. Toutefois, construire des relations significa-

About the authors: olajumoke F. OgUnSANYa Durban University of Technology, South Africa. Email: olajumokesanya@gmail.com

IVAN G. GOVENDER Durban University of Technology, South Africa. Email: ivang@dut. ac.za 
tives et durables constitute une tâche complexe dont le processus est semé de tensions qui entravent l'atteinte des objectifs fixés. Une analyse documentaire a été conduite en utilisant une lecture critique de la littérature disponible pour examiner ces tensions, avec pour objectif de mettre en avant comment elles ralentissent l'institutionnalisation de l'engagement communautaire au sein des universités. L'article identifie aussi de futures tendances dans l'engagement communautaire dans le secteur de l'enseignement supérieur, avec une focalisation particulière sur l'impact de la technologie.

\section{Introduction}

The character of Higher Education (HE) has shifted in line with evolving conceptualisations of the role of universities in society. Many universities' mission statements now include the development of close relationships with external stakeholders in order to address societal problems. Such efforts are linked to their other academic functions of teaching and research. Higher Education Institutions (HEIs) are under pressure to promote societal wellbeing by addressing socio-economic, developmental and environmental needs in their immediate communities (Dempsey, 2010; Morris et al., 20II). These pressures stem from shifts in local and global political and socio-economic trends as well as broad expectations among key stakeholders that they will link their traditional academic roles with practical real world issues (Boyer, I996, I990; Fitzgerald et al., 2012; Welch, 2016).

The Carnegie Foundation (2006) describes community engagement (CE) as fostering mutually beneficial relationships between HEIs and external stakeholders or communities in a context of cooperation and exchange of resources. Such interaction can occur at local, national, regional or global level. 'Communities' include businesses, industry, schools, government, non-governmental organisations (NGOs), or social communities. Community engagement is regarded as a way of expanding teaching and research to involve those outside of academia who are equipped with skills, acumen, and experiences that can contribute to the quality of universities' scholarly agenda in ways that produce solutions to societal problems. Engagement is aimed at achieving mutually beneficial goals. However, the relationship between universities and their diverse communities is multifaceted and tensions often arise due to inherent differences in stakeholders' ethos, principles and expectations. This article examines such tensions and how they can be managed to ensure a sustainable future for university-community engagement (U-CE). Given the demands placed on HE by the impending fourth industrial revolution (4IR), it also focuses on the role of technology in future CE trends.

An exploratory approach was adopted and a literature review and desktop documentary analysis of books, journal articles and policy reports were employed to review current tensions in U-CE and their impact on its institutionalisation in HEIs. The HE sector is experiencing on-going transformation and documentary analysis was deemed appropriate to examine a range of perspectives and offer insight into the possible future focus of $\mathrm{HE}$ CE. Search keywords associated with the subject matter were used to locate appropriate and relevant literature. They included community engagement; higher education; higher education community engagement; universitycommunity engagement; community partnership; community-engaged scholarship; community engagement challenges; community engagement tensions; and monitoring and evaluation. The keywords were combined to form search phrases which were applied to database searches. The criteria for selection of the literature included publications in the English language since the year 2000 as robust research has been conducted on CE in HE since that date. Another criterion was publications that contain at least one keyword in their title or abstract. Books, peer-reviewed journal articles, government publications and policy reports were reviewed. The analysis presented in this article is part of a broader study supported by the National Research Foundation to advance knowledge around CE in South African HEIs.

\section{Literature Review}

Given the complex nature of the challenges that CE seeks to address, systems theory was an appropriate theoretical framework. The functioning of the complex whole, that is, a system, is influenced by its parts and the interaction between those parts (Jackson, 2003). Senge (I990) asserts that systems theory offers a means of addressing, using and understand the whole while taking into account the networks of relationships between the parts and how these relationships give rise to and sustain the existence of the entity that is the whole. The theory of system dynamics in systems theory posits that numerous variables exist in systems (Jackson, 2003). Jackson adds that causal relationships exist among these variables that arise from interactions and feedback mechanisms connecting one variable to another, thereby shaping the complex and dynamic characteristics which systems use to evolve over time. According to Witter et al. (20I3), a systems approach seeks to understand the underlying causes of observed changes (or the reasons why change has not transpired), as well as the manner and context in which observed changes occur.

In applying the systems perspective to $\mathrm{CE}$, the analysis is widened to take into account the contextual factors underpinning complex problems. The institutional infrastructure (such as institutional policies, dedicated campus engagement offices/units, human resources, funding, rewards 
and remuneration systems, and monitoring and evaluation systems) in place in a university to support CE creates a platform from which CE initiatives, projects or programmes can run efficiently. The notion of a platform embodies the concept of a system which is a cluster of interrelated activities, resources and individuals that interact within an entity (Welch, 20I6). Thus, the analysis looks beyond individual parties to understand how tensions in one part can affect the functioning of the entire relationship.

\section{Institutional Complexities}

Several authors have highlighted the factors that impose pressure on HE systems. These include massification through which expanded access has been achieved (De Villiers and Nieuwoudt, 20I0). Fuelled by new technological developments, globalisation has enabled large scale interconnectedness, and rapid information diffusion and has created new platforms for formal and non-formal learning (Stromquist and Monkman, 20I4; Lorenzo and Gallon, 20I5). However, universities are confronted by financial constraints due to rising costs as well as changes in the sources and levels of income (Fielden, 2008). High dropout rates and the poor skills complement of graduates remain a challenge (Higher Education South Africa (HESA), 2009). The introduction of new public management (NPM) principles in HE has led to demands for increased accountability (Benneworth, 2013). Furthermore, while it is regarded as a core function, $\mathrm{CE}$ is perceived to dilute both the academic culture and common purpose of HE (Van Schalkwyk, 20I5).

Current issues confronting South African HE include demands for free education, the need for demographic diversity in the staff and student complement, and violent student protests. Furthermore, the sector continues to grapple with apartheid legacies, including poor infrastructure in previously disadvantaged universities, Eurocentric curriculum content and epistemological traditions, and a substandard schooling system, leading to student under-preparedness for HE (Govender, 20I8; Heleta, 20I6; Letsekha, 20I3; Subotzky and Prinsloo, 20II). Against this backdrop, crafting strategies to engage with and meet the expectations of external stakeholders is a delicate balancing act.

One of the ways universities are responding to pressure to change is the adoption of new governance and leadership models (Gayle et al., 2003) such as NPM from the public sector, which has resulted in traditional collegial governance practices being replaced by business-oriented leadership and management styles (Enders et al., 2013; Tahar and Boutellier, 2013; Bleiklie and Lange 20I0). This has had a major impact on the coordination of HE and institutional functions (Reihlen and Wenzlaff, 2OI4). New public management in HE emphasises key elements such as marketisation where funding is concerned; an entrepreneurial disposition; a client-oriented HE system (or student-centredness); measurement of outputs and performance; quality assurance measures; academic audits; institutional rankings; strategic planning; and increased accountability to stakeholders such as policy-makers and the public (Reihlen and Wenzlaff, 20I4; Musselin, 20I3; Bleiklie and Lange 20I0; Ferlie et al., 2008). However, some scholars (Alonderiene and Majauskaite, 2016; Ferlie et al., 2008; Winter, 2009) have raised doubts about NPM's suitability for this sector. They contend that corporate management models create complexities for $\mathrm{HE}$ policy makers, university management, and academic and administrative staff, as well as students. Critics also argue that imposing models that were not designed for academia creates tension between scholarly academic work and the administrative aspects of the institution. In terms of the effect of NPM's managerial approach on CE, the authors argue that universities may be required to justify the value gained from efforts and resources deployed in CE initiatives.

Zomer and Benneworth (20II) assert that U-CE contributes directly to the growing complexity of contemporary universities' organisational form. Universities are traditionally described as hierarchical, loosely-coupled systems characterised by decentralised internal authority, semi-independent sub-units, and a high level of institutional autonomy from external interests (Bleiklie et al., 20I7; Pinheiro and Stensaker, 20I4). Freedom to engage in creative intellectual discourse and the autonomy of different academic disciplines are said to be the rationale for such vertically-oriented structures (Keeling et al., 2007). However, growth, reforms and diversification in HE continue to challenge HEIs' traditional organisational peculiarities. Effective CE requires multi-disciplinary cooperation or integration where expertise and knowledge from various disciplinary fields are harnessed to identify solutions to societal problems (Hoy and Johnson, 2013). Boyer (1996, I990) highlights the scholarship of integration where inter- and trans-disciplinary cooperation promote the discovery, interpretation and use of knowledge across different disciplines and wider contexts. Rigid separation of academic disciplines which gives rise to inward-looking, silo thinking is a challenge when semi-independent disciplinary communities - colleges or faculties, schools, departments - under one institutional umbrella operate along parallel lines (Hoy and Johnson, 20I3; Fitzgerald et al., 20I2; Fitzgerald and Simon, 2012; Johnson et al., 2010). This is compounded by competition amongst disciplines for intellectual superiority and innovation rather than learning from one another to achieve the same goal (Clifford and Petrescu, 20I2). Alongside decentralisation of governance and responsibility, revised funding models in many institutions have resulted in competition for scarce resources. The implication is 
that academic disciplines will naturally focus on pursuing their own goals, objectives and interests rather than those of a collective involving others in the greater university community (Clifford and Petrescu, 20I2).

In order to break down barriers, significant consideration must be given to organisational structures, management, and budgetary allocations which constrain academics who seek to undertake inter-disciplinary inquiry towards engagement (Weerts and Sandmann, 2008). Tensions between institutional elements generate and sustain complexities within universities. Moreover, there are different types of universities and each exists in its unique context which may be public, rural, urban, research-oriented, university of technology, comprehensive university or other typologies. A university's context influences how its CE is operationalised (Holland, 2005). The extent of this effect is an area for further research.

\section{Conceptual Ambiguities}

Debate continues on the meanings and definitions of key concepts in CE. 'Community' is central and significant to the concept and practice of CE because its characteristic feature is intentional collaboration between HEIs and their community stakeholders. The literature offers diverse interpretations and perspectives of $\mathrm{CE}$, raising important questions as to who constitutes the community in CE. Defining community is imperative for HEIs to determine who their community/communities is/are, and how they need to engage with them. It is also important for these institutions to consider where their community starts and ends. In the absence of such clarity, the engagement will be unfocussed and therefore less effective.

Strier (20I4) notes that different depictions of the community will influence the ways CE is defined and structured. Tumiel-Berhalter et al. (2005) observe that communities are comprised of multiple, dynamic layers. They are non-homogeneous and different members or stakeholders have different interests and opinions on the required course of action as well as expectations of engagement outcomes. Acknowledging communities' diversity provides an opportunity to examine and understand, amongst others, the critical socio-economic, political, cultural, environmental and technological influences that shape them and concomitantly shape university-community partnerships (Tumiel-Berhalter et al., 2005) as well as the politics involved in identifying and representing community interests (Dempsey, 20I0). Failure to recognise such differences may result in apathetic involvement, a false sense of unanimity, and the stifling of valuable dialogue and exchanges.

Different HEIs as well as their stakeholders interpret CE differently. In part due to the national and institutional contexts guiding universities' conceptual frameworks, (Slamat, 20I0), several terms are used to describe university activities under the umbrella of 'engagement'. The use of multiple terminologies also reflects debates and contestations around the term (Kruss, 2OI2) that are reflected in universities' commitment and approach to $\mathrm{CE}$ as well as their choices of development projects or CE activities. Some institutions still perceive communities as needy entities, resulting in a more philanthropic notion of engagement rather than regarding CE as a means of creating and sharing knowledge. Such a perception is responsible for universities making assumptions about what communities need without consulting them. The discussion around definitions centres on the key issues of the purpose, role and responsibility of the university (Favish and Simpson, 20I6).

In South Africa (SA), the highly differentiated HE sector results in different forms of U-CE. According to Higher Education South Africa (2009, p.8), SA's institutional diversity is "a system of progressive self-differentiation based on varying institutional visions and missions accompanied by policies and processes that enable institutions to make meaningful progress in their distinctive developmental trajectories". The global continuum of conceptual expressions of CE shows that CE is highly contextual. This impacts universities' CE processes, choice of stakeholder associations, and the outcomes of engagement (Archer-Kuhn and Grant, 20I4).

\section{Campus-Community Boundaries}

Community engagement draws attention to physical and social boundaries between universities and the world around them. Indeed, it has been argued that U-CE's defining feature - cooperation between universities and the larger community - contributes to the divide between academia and communities. According to Dempsey (20I0), such delineations establish boundaries around the university, thereby regarding community as extraneous. Consequently, "discussions of community engagement reinforce a strict campus-community divide that treats the university and the community as occupying distinctly different spheres and results in several problematic assumptions" (p.364). Dempsey adds that universities are complex institutions that have "various overlapping historical, political, and economic relationships with their surrounding communities" (p.364). Therefore, CE should consider such boundaries and be conscious of their influence on universities' ability to establish significant partnerships. Other factors that reinforce campus-community borders include a lack of understanding among some levels of university leadership with regard to the best way to achieve CE with communities (Weerts and Sandmann, 20I0). Corrigan (2000) adds that a narrow focus on research and teaching may cast community partners as passive participants, rather than partners in knowledge creation. 
In contrast to Dempsey, Giles (20I2) is of the view that the emergence of $\mathrm{CE}$ on the HE landscape as a third function of universities has contributed to a more porous border. As the norms and practices of research and teaching shift beyond the university, the reconfigured landscape provokes questions about the role and identity of academics in an environment where interaction across borders is transforming the core functions of academia. Tensions arise as they attempt to navigate new identities, roles and an expanded scope of work when the university interacts more with the outside world. The research inquiry is no longer detached and confined to a few fellow scholars (Giles, 20I2). It is also important to ensure that legitimacy, academic freedom, neutrality and the integrity of work with community stakeholders are sustained.

Lam (20I0) identifies four orientations that actively shape campuscommunity boundaries. At one end of the spectrum are traditionalists who strongly believe that academia and industry should be separate. They restrict their work to the academic space and avoid engaging with business or contest the legitimacy of work carried out by other academics with industry. At the other end are entrepreneurial academics who believe that the "importance of science-business collaboration for knowledge application and commercial exploitation" means that campus-community boundaries should be highly permeable (Lam, 20I0, p.3I7). Between these two extremes are hybrid orientations which combine the characteristics of both. According to Lam, traditional hybrids believe in distinct boundaries between the university and industry, but also understand the advantages of linkages in order to broaden knowledge. Finally, entrepreneurial hybrids hold a strong belief in the traditional norms and values of the university, but blend this with an entrepreneurial orientation. They regard access to the university and industry as a means for shared knowledge production and application.

To resolve the tensions arising from the campus-community divide, Weerts and Sandmann (20I0) propose the concept of 'boundary spanning', a multifaceted range of activities at individual and institutional levels aimed at building bridges between the university and community. At the individual level, boundary spanning involves individuals from within the university or community whose main responsibility is engaging stakeholders; negotiating power dynamics and consonance between the university and its external constituency to ensure shared goals are achieved; and ensuring that both sides' perceptions, expectations, and ideas are adequately represented or communicated (Sandmann et al., 20I4). Holland (2005) notes that the university's mission, history and physical location are significant factors with regard to institutional boundary spanning. It thus takes into account the multi-layered, multipurpose relationships that universities have with their community partners, reflecting these in broad approaches to engagement.
Boundary spanners from the university use their research, and teaching and learning roles to advance shared understanding between academe and the external community.

Warren et al. (2016) and Netshandama and Mahlomaholo (2010) consider participatory research to be strategic and useful in bridging the campus-community divide. Community-based participatory research privileges those being researched in the entire research process, thereby sharing ownership of knowledge production with participants (Bergold and Thomas, 20I2). Important outcomes include knowledge co-building and co-learning which can be directly advantageous to the stakeholders involved, while simultaneously shifting the typical power subtleties prevailing in the research process. In addition, efforts to resolve the tensions associated with campus-community borders should include broader lines of on-going communication between the university and communities to their mutual advantage.

\section{Power Relations}

The campus-community divide provides some insight into the power relations between universities and communities, and the effect thereof on communities' sense of belonging in collaborations. "Inter-relational power dynamics are (closely) connected to the success of any relationship and are especially critical in developing and sustaining mutually beneficial, reciprocal, engaged partnerships" (Sandmann and Kliewer, 20I2, p.I). It is important to unveil the power relationships in U-CE in order to understand the inherent dynamics and influence of power in different partnership formations; the partners' relative power in terms of resource capacity and what they bring to the shared forum; and the extent to which they are obligated or agree to be bound to partnership outcomes (Benneworth, 2013; Clifford and Petrescu, 20I2; Strier, 20I4). The phenomenological element of Freire's theory cited in Kliewer et al. (2OIO) posits that power is intrinsically involved in the generation of different constructs of knowledge. Striking a balance between knowledge from academia and that from communities is a major challenge of CE. Buys and Burnsnall (2007) cite two reasons for academia's disregard for knowledge that is available within communities. The first is that community members are regarded as subjects to be studied as opposed to being partners in research. The second is the perception that research with community members as research partners may lack the required rigour. On the other hand, communities may be reluctant to work with academics due to perceptions that they conduct research that is irrelevant to issues affecting communities, and exhibit attitudes that are condescending, manipulative and secretive towards communities (Ahmed et al., 2004). The clash between academics' 'expert's mindset' (Bernardo et 
al., 20I4, p.II5) and the community's experiential knowledge often causes tensions.

Power differentials between academia and communities are a major source of tension because they tend to impede collaboration and introduce conflicts which can potentially undermine CE objectives (Sandmann and Kliewer, 20I2; Archer-Kuhn and Grant, 20I4; Dempsey, 20I0; Maurrasse, 200I). Since the power balance is often tilted in favour of academia, the inference is that universities are positioned to drive the agenda of community partnerships. As a result, they tend to derive more benefit from community partnerships than communities, which creates resentment and mistrust between the partners (Strier, 20II).

According to Wiewel and Knaap (2005), the unequal power relations noted in U-CE reflect the social imbalances in society at large because many partnerships are made up of representatives from different social segments. Strier (20I4, p.I59) asserts that "the institutional and societal hierarchies in which participants are embedded are transferred into the university-community partnership". Notions of power inequalities, real or presumed, exist between universities and their community partners around physical space, professional stature, knowledge and skills, and resources and privilege. This can deter or invalidate the objectives of CE. Community engagement promotes a paradigm of reciprocity and mutuality which if adopted by universities, aims to contribute to more balanced power relations with communities. Using a relational engagement framework, Freire $(2000$, cited in Kliewer et al., 20I0) makes a case for U-CE partners to acknowledge that knowledge does not solely reside in academia, and that communities are valid co-creators and consumers of knowledge. Therefore, in promoting shared learning platforms towards developing informed perspectives on social issues, U-CE partnerships will not be one-sided and reciprocity can be achieved. Fitzgerald et al. (20I7) state that communities' active involvement confers realism and authenticity on knowledge. Preece (2016) and Hart et al. (2013) thus suggest that dialogue, respect for a diversity of views and a consultative leadership approach can be employed to redress power imbalances. Two-way exchange facilitates cooperation between academics and communities to explore, discover and learn. Bringle and Hatcher (2000) recommend that universities adopt flexible governance structures that will enable them to adapt to different situations, as well as institutional structures that are accessible to communities.

Transformational Leadership

Clark (20I7), Bernado et al. (20I4), Driscoll (2008), Miller (2008) and Winter et al. (2006) note that leadership is crucial in promoting institutional commitment to CE. According to Weerts and Sandmann (2008), leadership is able to influence and facilitate U-CE due to two factors. The first is management's role in championing and communicating the value of engagement internally within the university environment and externally with all community stakeholders. Secondly, leadership has the requisite authority to incorporate CE into institutional policy and structures, as well as to allocate resources to promote engagement. This implies that leadership legitimises CE as an academic activity, and is instrumental in strengthening an institution's identity and image as an engaged institution. Fitzgerald et al. (20I7) cite policy making, resource support and leading by example as ways in which leadership can inspire faculty to promote social justice and responsibility in their teaching and research. Bernado et al. (20I2, p.I9I) found that leadership is key if CE is to be "elevated from a set of practices of doing things, towards a philosophical belief of the university's reason for being".

However, leadership can be a source of tension in CE when university leadership and management show reluctance, disinterest, or a lack of understanding of how the institution will engage with its diverse external communities. It is necessary to address key issues such as outlining specific and appropriate roles for leadership and academic staff in partnership or engagement initiatives; identifying those best-positioned in the institution to advocate for CE internally and externally; and delineating the extent to which university representatives act in the interests of the institution or community in the engagement partnership (Weerts and Sandmann, 20I0). Leadership must have the acumen to strategically and appropriately balance an institution's capacity, responsibilities and interests with society's needs (Bernardo et al., 20I2). The end goal of engagement is to reposition universities from simply getting things done to being wholly transformed in terms of institutional philosophy, staff, students, and communities. This line of thought influences Jacoby's (2014) proposition that transformational leadership is required to propel academe to a heightened sense of responsibility in making a difference in communities. Likewise, Govender (2018) advances that transformational leadership is essential in order to inspire academia to combat social injustice and inequalities where the university champions the development of intellect and knowledge for improving society.

In post-apartheid SA, U-CE can be said to be development-driven in view of the African National Congress (ANC) government's prioritisation of $\mathrm{HE}$ as a major means of economic development (Edigheji, 20Iо; Routley, 20I4; Subban and Vyas-Doorgapersad, 20I4). In a bid to link economic imperatives to the social challenges faced by the majority of the population, CE-informed teaching and research is intended to provide useful solutions to industry, government, and society (Winberg, 2006). South Africa con- 
fronts the major socio-economic challenges of entrenched inequality, high levels of unemployment, persistent poverty, food insecurity, and the HIV and AIDS pandemic, amongst others. McNall et al. (20I5, p.I) describe these as "complex dynamic systems of problems that interact and reinforce each other over time". McNall et al. add that such problems elude simple solutions due to the complexity of the system in which they are embedded such that an attempt to resolve one element of the problem is lost and ineffective in the intricate dynamics of the complex system. The nature of the problems demands an approach that draws on capacity and experiences from various disciplines. This will advance collaboration across domains and result in varied perspectives of professional, social and cultural knowledge and experiences (Ramaley, 20I4). Community engagement requires proficient academics who, on the one hand, are able to tackle problems with current knowledge, and on the other, engage in transdisciplinary teamwork to develop new solutions to entrenched problems. Universities confront this challenge at the interconnection between teaching and learning to educate students, research to generate knowledge and CE with issues relevant to society's well-being (Ramaley, 20I4).

Fitzgerald et al. (20I7, p.49) maintain that "confronting problems within the context of community-university interplay can facilitate the development of conceptual and quantitative models designed to assess the relation between programmatic interventions and the complex systems one is attempting to change". We argue that CE enables HEIs to mobilise new ways of educating in view of the changing roles of $\mathrm{HE}$ as well as the complex problems confronting society. Various elements of inquiry and action need to coalesce in order to develop new thinking about the interconnected challenges. Fresh understanding of the problems confronting society and improved solutions require a broad spectrum of stakeholders to own and take responsibility for shared strategies and processes. The changing world of academia requires committed leadership that is able to connect academia to the experiences and knowledge obtainable in the broader community in order to create a co-dependent ecosystem of engaged scholarship, teaching and learning.

\section{Monitoring and Evaluation}

In $\mathrm{CE}$, it is logical to expect that initiatives and collaboration will yield outcomes which lead to some level of change (Coetzee, 20I2). Measuring the change due to specific interventions is important in order to improve planning, performance and learning within the organisation (Estrella, 2000). Monitoring and evaluation (M\&E) systems appraise performance to establish the outputs, outcomes and results of a project, programme or intervention (Frankel and Gage, 20I6). The purpose is to determine how well a programme, initiative or strategy is working and to identify the causes of success or failure (Naidoo, 20II).

$\mathrm{M} \& \mathrm{E}$ in U-CE is also a means of building accountability measures into CE practices. We argue that accountability is an integral element that can improve the quality of processes as well as the outcomes of U-CE in all its expressions. Accountability, organisational learning and effectiveness remain difficult to determine in CE due to a dearth of established and effective M\&E systems. Contributory factors include CE's marginal status in many universities as well as a very fragmented, silo approach to practice, and a lack of focus on outcomes (Dempsey, 20Iо; Jongbloed and Benneworth, 2013; Hatcher, 20II). The evaluative element in CE is insufficient as basic tracking and documentation of engagement activities, project performance and results are not comprehensive (Driscoll, 2009). Although $\mathrm{M} \& \mathrm{E}$ tools are being developed, they differ considerably in terms of focus, intent, and scope among others (Hart and Northmore, 20II; Furco and Miller, 2009; Weerts and Sandmann, 2008). This leads to inconsistency in measurement indicators. Unlike in research and teaching and learning, there are no universal codes or practices to determine the quality of CE.

Reaching consensus on best practices in South African U-CE has been problematic because HEIs are not required to document and report on their $\mathrm{CE}$ activities. There is thus no national database on such activities (Favish and Simpson, 20I6). M\&E is critical for good governance, quality assurance and sustainable management and to ensure that CE practices achieve the objectives of both universities and communities. As U-CE expands and is integrated into the academic core of institutions, it will become even more crucial to articulate and assess the clarity of direction of these efforts. We thus propose that M\&E systems should be designed to provide some commonality on what to monitor and evaluate to ensure compliance.

\section{Technology}

The influence of technology in CE is pertinent in view of rapid developments in digital, information and communication technology. The 4IR is expected to radically transform societies through the emergence of new exponential technologies and processes (Penprase, 20I8). Realities emanating from the 4 IR include the integration of physical, biological and digital technologies and the compounding effects such as big data analytics, artificial intelligence, cognitive technologies and the Internet of things (Xing and Marwala, 20I7). These technologies are instrumental in the creation of interconnected, interdependent digital enterprise systems or cyber-physical systems that are capable of extensive, informed and intelligence-based decision-making (Xing and Marwala, 20I7). Schwab (20I6) notes that the key features of the 4IR are speed, as the evolution of newer 
and more capable technology occurs at an exponential rather than a linear pace; its breadth and depth due to the combination of multiple technologies resulting in unprecedented paradigm shifts in the "what" and the "how" of doing things as well as "who" we are; and the multifaceted impact on systems where entire systems, across and within countries, economies, businesses, industries and society as a whole are transformed. The impact of the 4IR will largely depend on how people elect to use the new technologies, and HE can be instrumental in the adjustments students, academics and society have to make (Gleason, 20I8). In terms of CE, future trends may depend on how technological advancements can be used to further U-CE activities in improving communities' quality of life.

It is envisaged that the 4IR will reshape society and subsequently affect how humans live and relate to one another. According to Xing et al. (2018), its effects will include benefits (value creation and efficiency) as well as challenges (social/socio-economic, developmental). The tools that the $4 \mathrm{IR}$ provides can be used to tackle social issues which humanity stills grapple with, such as equity; inequality; poverty; resource scarcity; inclusivity; gender sensitivity and ethics. Butler-Adam (20I8) posits that the challenge to researchers is harnessing the sophistication and utility of 4 IR outcomes for society's development, sustainability and benefit.

Community engagement offers an avenue to take advantage of what the 4 IR offers society as new communication technologies have implications for CE activities. Dumova (2OI5) states that digital technologies' most pertinent characteristics are interactivity, asynchronicity, and de-massification. Interactivity is a fundamental feature of new technologies that ensures simultaneous and continuous exchanges to facilitate knowledge sharing (Jenkins, 2006; Metzger, 2009). Asynchronicity enables users of digital communication technologies to exchange communication at convenient times, thereby overcoming time as a barrier to interaction and taking control of interaction (Dumova, 20I5). De-massification offers highly individualised new media where personal communication is possible with individuals in a crowd.

Our evaluation of technology in U-CE considers three approaches, namely, communication technology as an agent of social change, community informatics, and the socio-technical approach (Dumova, 20I5). Communication technology that is instrumental in social change, emphasises the use of the Internet and other media technologies to stimulate civic involvement (Vicente and Novo, 20I4). In a global knowledge economy where information and knowledge exchange is pertinent for economic participation and development, information and communication technologies (ICTs) provide a platform for social and economic inclusion (Gurstein, 2000). Community informatics offers a multidisciplinary angle from which to explore how socio-cultural factors affect dissemination of new ICTs, and their subsequent effects on community development, regeneration and sustainability (Keeble and Loader, 200I). The convergence of new media and ICTs has advantages which, when harnessed, become catalysts for socio-economic stimulation of communities. In research and practice, a university can use community informatics to connect advancements in ICTs with problems related to socio-economic development, political inclusion and cultural expansion of communities in order to improve their well-being and welfare (Dumova, 20I5; Pierson, 2000). Digital technologies are used to connect cyber space to the community place by bridging the digital divide evident in unequal access to technology in different sections of society, or the gross disparities in ICT availability between industrialised and developing countries (Robinson et al., 20I5; Pearce and Rice, 2013).

Finally, the socio-technical approach focuses on the characteristics, functions, and advantages that technology brings to the evolution of communication within and between communities to effect social change (Lin and Atkin, 2007; Metzger 2009). Appreciation of the social perspective in which evolving digital technologies can be applied will contribute to the use of technology in U-CE initiatives. Technology can be used as a facilitator of the process of engagement, as an innovation which is the product of knowledge co-development and as a solution deployed to uplift communities.

\section{Discussion}

Figure I depicts engagement dynamics between universities and their communities as U-CE progresses from the past to an envisioned ideal in the future. The state of U-CE in the past is illustrated by a solid line representing well-defined borders, figurative and physical, between HEIs and local communities. Each occupies a demarcated space with very little room for engagement in the real sense. In line with Benneworth (2013) and Weerts and Sandmann (2008), we argue that the observed demarcation between universities and communities arises from structural divides, institutional issues and the characteristics of both institutions and communities. Structural divides represent visible and invisible barriers that make it difficult for outsiders to engage with the university and vice versa. They include the physical location or layout that cordons off an institution from those beyond its walls, a lack of correlation between the idea of CE and an institution's core mission, or the fact that surrounding communities may not fit into an institution's provisions for engagement. Institutional issues and characteristics include, among others, a lack of coherent CE policies as well as funding and incentives for CE, and a poor fit between CE practices or mechanisms and what is required by communities, as well as certain stances taken by communities which lead them to resist CE overtures from 
the university, thus extending their distance. Apartheid policies contributed to the divide between universities and communities in SA, with the former separated from the latter on the basis of race.

Figure 1. University-Community Engagement Dynamics

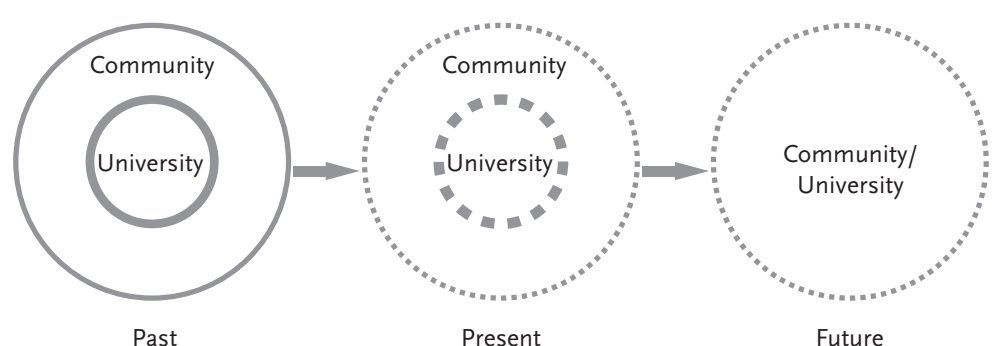

In the scenario described as the past, HEIs' approach to proffering solutions to the complex social problems confronting society was through a uni-directional model of outreach where knowledge was produced using traditional research methodologies and was disseminated to the community via one-way broadcasts. Community partners had little input into the process of knowledge development and were regarded as consumers of knowledge or recipients of products of knowledge regardless of its suitability to their context.

The present state of HE CE is depicted by the boundary of a dotted line between the university and community rather than a solid one. Although they maintain their distinct and separate existence, the university boundary has become more permeable to allow those within HEIs and the community access to one another's domains. Such accessibility is by invitation and as a result can still be regarded as limited, with CE not yet reaching its potential. This state is further deepened by contemporary university settings where CE is often found in pockets of isolation in discrete domains through the individual work of academics. Nonetheless, universities have been able to develop and maintain different levels of relationships with external stakeholders in areas of shared interest. To this end, they have demonstrated service to society to some degree, notwithstanding the aforementioned tensions.

Going forward, we propose an ideal status of CE where universities are intimately established within their communities such that there is a seamless link between a university and its local, national, regional and international communities. Likewise, communities have access to and are integrated with HEIs, creating equal and positive partnerships that have a sustainable impact on society. The manner in which a university approaches its educational mission should be such that curriculum design and delivery facilitates learning from both within and without. This will signify true cooperation where U-CE partners create and share knowledge for mutual benefit. As such, the educational environment transcends the typical lecture hall, extending into the community which itself becomes both a classroom and a knowledge site for all to learn at any time, in any setting.

In exploring the future of $\mathrm{CE}$, we also considered the role and impact of technology on U-CE. Digital technologies facilitate communication, creating an expansive space for knowledge exchange. A technology-driven U-CE future thus includes boosting innovation through ready availability of and access to large volumes of real time data and information. Since knowledge transfer is a significant part of many universities' objectives, the role of technology in U-CE is important in disseminating innovative ideas. Propagation of knowledge, information, skills, and technologies in CE can be implemented in various ways. It can also occur at different levels between and amongst the various communities that universities engage with to meet relevant needs in society.

\section{Conclusion}

University-community engagement is gradually being accepted as a valuable aspect of the academic function. It is a useful strategy for universities in building mutually beneficial relationships with external stakeholders and advancing transformation. In partnership with other sectors, CE is a means for HE to contribute to public well-being because CE initiatives have the potential to contribute to the transformation and sustainability of both universities and communities. At the same time, there is a need for better understanding of the tensions and challenges involved in these efforts, and how they impact all parties. This article identified and discussed the key sources of tensions in U-CE as well as possible future trends in light of the application of technology in CE initiatives. It is suggested that further research should focus on outcomes on both sides of U-CE.

\section{References}

Ahmed, S. M., Beck, B., Maurana, A., and Newton, G. (2004). Overcoming barriers to effective community based participatory research in US medical schools. Education for Health 17(2), I4I-I5I.

Alonderiene, R., and Majauskaite, M. (2016). Leadership style and job 
satisfaction in higher education institutions. International Journal of Education Management 30 (I), I40-I64.

Archer-Kuhn, B., and Grant, J. (20I4). Challenging contextual factors in university-community partnerships. Journal of Community Engagement and Scholarship 7(2), 40-49.

Benneworth, P. (2013). Towards the idea of "The Engaged University". In P. Benneworth (ed.), University engagement with socially-excluded communities (pp.3-3I). Dordrecht: Springer.

Bergold, J., and Thomas, S. (20I2). Participatory research methods: A methodological approach in motion. Historical Social Research 37(4), I9I-222.

Bernardo, M.A.C, Butcher, J., and Howard, P. (20I4). The leadership of engagement between university and community: Conceptualizing leadership in community engagement in higher education. International Journal of Leadership in Education 17(I), I03-I22.

Bernardo, M.A.C, Butcher, J., and Howard, P. (20I2). An international comparison of community engagement in higher education. International Journal of Educational Development 32(I), I87-I92.

Bleiklie, I., Enders, J., and Lepori, B. (20I7). Setting the stage: Theory and research questions. In I. Bleiklie, J. Enders, and B. Lepori (eds), Managing universities: Policy and organizational change from a western European comparative perspective (pp.3-29). Cham, Switzerland: Palgrave Macmillan.

Bleiklie, I., and Lange, S. (2010). Competition and leadership as drivers in German and Norwegian university reforms. Higher Education Policy 23(2), I73-I93.

Boyer, E.L. (I996). The scholarship of engagement. Bulletin of the American Academy of Arts and Sciences 49(7), I8-33.

Boyer, E.L. (I990). Scholarship reconsidered: Priorities of the professoriate. Princeton: Carnegie Foundation for Advancement of Teaching. Retrieved March 26, 20I8, from: https://files.eric.ed.gov/fulltext/ ED326I49.pdf

Bringle, R.G., and Hatcher, J.A. (2000). Institutionalization of service learning in higher education. The Journal of Higher Education 71(3), 273-290.

Butler-Adam J. (2018). The fourth industrial revolution and education. South African Journal of Sciences 114(5/6), I. Retrieved November I7, 2018, from: http://dx.doi.org/IO.I7I59/sajs.20I8/ao27I

Buys, N., and Bursnall, S., (2007). Establishing university-community partnerships: Processes and benefits. Journal of Higher Education Policy and Management 29(I), 73-86.

Carnegie Foundation. (2006). The Carnegie Foundation for the Advance- ment of Teaching. FAQs. Retrieved November 2I, 20I7, from: https:// www.brown.edu/swearer/carnegie/about

Clark, L. (20I7). Implementing an institution-wide community-engaged learning program: The leadership and management challenge. In J. Sachs and L. Clark (eds), Learning through community engagement Vision and practice in higher education (p.I33-152). Singapore: Springer.

Clifford, D., and Petrescu, C. (20I2). The keys to university-community engagement sustainability. Nonprofit Management and Leadership 23(I), 77-91.

Coetzee, E. (20I2). Community engagement by higher education institutions - A practical model and guidelines. Africa Education Review, 9(3), 5OI-5I7

Corrigan, D. (2000). The changing role of schools and higher education institutions with respect to community-based interagency collaboration and inter-professional partnerships. Peabody Journal of Education 75(3), I76-I95.

Dempsey, S.E. (20I0). Critiquing community engagement. Management Communication Quarterly 24(3), 359-390.

De Villiers, P., and Nieuwoudt, L. (20I0). Shifting trends in higher education funding. Bureau for Economic Research/Stellenbosch Economic Working Papers No. I2/20IO. Retrieved February II, 20I4, from: https://www.sun.ac.za

Driscoll. A. (2008). Carnegie's community-engagement classification: Intentions and insights. Change: The Magazine of Higher Learning 4O(I), 38-4I.

Driscoll, A. (2009). Carnegie's new community engagement classification: Affirming higher education's role in community. New Directions for Higher Education 147, 5-12.

Dumova, T. (20I5). Engaging technology in university-community partnerships. In W.J. Jacob, S.E. Sutin, J.C. Weidman., and J.L. Yealger (eds), Community engagement in higher education - Policy reforms and practice (pp.5I-7I). Rotterdam: Sense Publishers.

Edigheji, O. 20IO. Constructing a democratic developmental state in South Africa: potentials and challenges. In O. Edigheji (ed.) Constructing a democratic developmental state in South Africa (pp.I-33). Cape Town: Human Sciences Research Council.

Enders, J., De Boer, H., and Weyer, E. (2013). Regulatory autonomy and performance: The reform of higher education re-visited. Higher education 65(I), 5-23.

Estrella, M. (2000). Learning from change. In M. Estrella, J. Blauert, J. Gonsalves, D. Campilan, J. Gaventa, I. Guijt, D. Johnson, and R. Ricafort (eds), Learning from change: Issues and experiences in participatory 
monitoring and evaluation (pp.I-I4). London: ITDG Publishing and IDRC.

Favish, J., and Simpson, G. (20I6). Community engagement. In South African higher education reviewed: Two decades of democracy (pp.24I278). Pretoria: Council on Higher Education.

Ferlie, E., Musselin, C., and Andresani, G. (2008). The steering of higher education systems: a public management perspective. Higher Education $56(3), 325-348$.

Fielden, J. (2008). Global trends in university governance. Education Working Paper Series No.9. Washington: The Word Bank. Retrieved May 26, 20I8, from: https://www.researchgate.net/publication/ 448390I7_Global_trends_in_university_governance

Fitzgerald, H.E., Bruns, K., Sonka, S.T., Furco, A., and Swanson, L. (2012). The centrality of engagement in higher education. Journal of Higher Education Outreach and Engagement 16(3): 7-27.

Fitzgerald, H.E., and Simon, L.A.K. (20I2). The World Grant ideal and engagement scholarship. Journal of Higher Education Outreach and Engagement 16(3), 33-55.

Fitzgerald, H.E., Van Egeren, L.A., Bargerstock, B.A., and Zientek, R. (20I7). Community engagement scholarship, research universities, and the scholarship of integration. In J. Sachs, and L. Clark (eds), Learning through community engagement - Vision and practice in higher education (pp.3I-52). Singapore: Springer.

Frankel, N., and Gage, A. M\&E fundamentals: a self-guided mini-course. 20I6. Measure evaluation. MS-07-20. Retrieved March 03, 2019, from https://www. globalhealthlearning. org/course/me-fundamentals.

Furco, A., and Miller, W. (2009). Issues in benchmarking and assessing institutional engagement. New Directions for Higher Education 2009 (I47), 47-54.

Gayle, D.J., Tewarie, B., and White, Jnr, A.Q. (2003). Governance in the twenty-first century university: Approaches to effective leadership and strategic management. ASHE-ERIC Higher Education Report 30(I). San Francisco: Jossey-Bass.

Giles, H. (2012). Negotiating the boundary between the academy and the community. In D. Butin, and S. Seider (eds) The engaged campus: Majors, minors, and certificates as the new community engagement (pp.4968). New York: Palgrave Macmillan.

Gleason, N.W. (ed). (20I8). Higher education in the era of the fourth industrial revolution (pp.I- I2). Singapore: Palgrave Macmillan.

Govender, I. (20I8). Transformative leadership enhancing community engagement in higher education institutions in South Africa. In V. Ribiere (ed.), $6^{\text {th }}$ International Conference on Management Leadership and Governance, 24-25 May 2018 (pp.I03-IIo). Reading, UK: Academic Conferences and Publishing Limited.

Gurstein, M. (ed.) (2000). Community informatics: Enabling community uses of information and communications technology. Hershey, Pennsylvania: IGI Global.

Hart, A., Davies, C., Aumann, K., Wenger, E., Aranda, K., Heaver, B., and Wolff, D. (20I3). Mobilising knowledge in community-university partnerships: What does a community of practice approach contribute? Contemporary Social Science 8(3), 278-291.

Hart, A., and Northmore, S. (20II). Auditing and evaluating universitycommunity engagement: Lessons from a UK case study. Higher Education Quarterly 65(I), 34-58.

Hatcher, J.A. (20II). Assessing civic knowledge and engagement. New Directions for Institutional Research $20 \mathrm{II}(\mathrm{I} 49), 8 \mathrm{I}-92$.

Heleta, S. (20I6). Decolonisation of higher education: Dismantling epistemic violence and Eurocentrism in South Africa. Transformation in Higher Education 1(I), I-8.

Higher Education South Africa. (2009). Pathways to a diverse and effective South African higher education system: Strategic Framework 2010-2020. Pretoria: HESA.

Holland, B. A. (2005). Institutional differences in pursuing the public good. In A. J. Kezar, T. C. Chambers, and J. C. Burkhardt (eds), Higher education for the public good: Emerging voices from a national movement (pp.235-259). San Francisco: Jossey-Bass.

Hoy, A., and Johnson, M. (20I3). Deep, pervasive, and integrated: Developmental frameworks for students, partnerships, faculty engagement, and centres. In A. Hoy, and M. Johnson (eds), Deepening community engagement in higher education: forging new pathways (pp.I-26). New York: Palgrave Macmillan.

Jackson, M.C. (2003). Systems thinking: Creative holism for managers. Chichester, England: John Wiley and Sons.

Jacoby, B. (20I4). Civic engagement in higher education: Moving from transaction to transformation for students and communities. Retrieved September 2I, 20I8, from: http://sla.fgu.edu.tw/attachments/article /ı24/FINAL\%20FINAL\%20CEIHE\%20-\%20NTNU\%20I2-8-I4.pdf

Jenkins, H. (2006). Convergence culture: Where old and new media collide. New York: New York University Press.

Johnson, B., Louw, A., and Smit, J. (2010). The new generation university: Views on knowledge and knowledge generation. In R. Townsend (ed.), Universities of Technology - Deepening the debate, Kagisano Series 7 (pp.II3-I27). Pretoria: Council on Higher Education.

Jongbloed, B., and Benneworth, P. (20I3). Learning from History - Previous 
attempts to measure universities' community impacts. In P. Benneworth (ed.), University engagement with socially excluded communities (pp.263-283). Dordrecht: Springer.

Keeble, L., and Loader, B. D. (200I). Community informatics: Themes and issues. In D. Eagle, B. Hague, L. Keeble, and B.D. Loader (eds), Community informatics - Shaping computer-mediated social relations (pp.I-Io). London: Routledge.

Keeling, R.P., Underhile, R., and Wall, A.F. (2007). Horizontal and vertical structures: The dynamics of organization in higher education. Liberal Education 93(4), 22-3I.

Kliewer, B., Sandmann, L.R., Kim, J., and Omerikwa, A. (2010). Toward understanding reciprocity in community-university partnerships: An analysis of theories of power. In Adult Education Research Conference Proceedings, 4-6 June (pp.256-26I). Kansas: New Prairie Press. Retrieved January I6, 20I9, from: http://newprairiepress.org/ aerc/2010/papers/42

Kruss, G. (20I2). Reconceptualizing engagement: A conceptual framework for analyzing university interaction with external social partners. South African Review of Sociology 43(2), 5-26.

Lam, A. (20I0). From 'ivory tower traditionalists' to 'entrepreneurial scientists'? Academic scientists in 'fuzzy' university-industry boundaries. Social Studies of Science 40(2), 307-340.

Letsekha, T. (2013). Revisiting the debate on the Africanisation of higher education: An appeal for a conceptual shift. The Independent Journal of Teaching and Learning 8(1), 5-18.

Lin, C.A., and Atkin, D.J. (2007). Communication technology and social change: Theory and implications. Mahwah, New Jersey: Lawrence Erlbaum Associates.

Lorenzo, N., and Gallon, R. (2015). Higher education and globalization. In New voices in higher education research and scholarship (pp.I27-156). Hershey, Pennsylvania: IGI Global.

Maurrasse, D. J. (200I). Beyond the campus: How colleges and universities form partnerships with their communities. New York: Routledge.

McNall, M.A., Barnes-Najor, J.V., Brown, R.E., Doberneck, D.M., and Fitzgerald, H.E. (20I5). Systemic engagement: Universities as partners in systemic approaches to community change. Journal of Higher Education Outreach and Engagement 19(I), 7-32.

Metzger, M. (2009). The study of media effects in the era of internet communication. In R.L. Nabi, and M.B. Oliver (eds), The Sage handbook of media processes and effects (pp.56I-576). Thousand Oaks, California: Sage Publishers.

Miller, P.M. (2008). Examining the work of boundary spanning leaders in community contexts. International Journal of Leadership in Education 11(4), 353-377.

Morris, M., Schindehutte, M., Edmonds, V., and Watters, C. (20II). Inner city engagement and the university: Mutuality, emergence and transformation. Entrepreneurship and Regional Development 23(5-6), 287-315.

Musselin, C. (2013). How peer review empowers the academic profession and university managers: Changes in relationships between the state, universities and the professoriate. Research Policy 42(5), II65-II73.

Naidoo, I. A. 20II. The role of monitoring and evaluation in promoting good governance in South Africa: A case study of the Department of Social Development. PhD thesis, University of the Witwatersrand, Johannesburg.

Netshandama, V., and Mahlomaholo, S. (2010). The role of community engagement in higher education: Focus on the discourse relating to knowledge development. In N. Basov, G.F. Simet, J. van Andel, M.G. Mahlomaholo, and V. Netshandama (eds), Critical issues: Imagining research in multidimensional perspective. Oxford: United Kingdom.

Pearce, K.E., and Rice, R.E. (20I3). Digital divides from access to activities: Comparing mobile and personal computer Internet users. Journal of Communication 63(4), 72I-744.

Penprase, B.E. (20I8). The fourth industrial revolution and higher education. In N.W. Gleason (ed.), Higher education in the era of the fourth industrial revolution (pp.207-229). Singapore: Palgrave Macmillan.

Pierson, J. (2000). Community informatics for electronic democracy: Social shaping of the digital city in Antwerp (DMA). In M. Gurstein (ed.), Community informatics: Enabling communities with information and communication technologies (pp.25I-272). Hershey, Pennsylvania: Idea Group Publishing.

Pinheiro, R., and Stensaker, B. 20I4. Designing the entrepreneurial university: The interpretation of a global idea. Public Organization Review 14(4), 497-516.

Preece, J. (20I6). Negotiating service learning through community engagement: Adaptive leadership, knowledge, dialogue and power. Education as Change 20(I), I04-I25.

Ramaley, J.A. (20I4). The changing role of higher education: Learning to deal with wicked problems. Journal of Higher Education Outreach and Engagement 18(3), 7-22.

Reihlen, M., and Wenzlaff, F. (20I4). Institutional change of the German higher education system: From professional dominance to managed education. In A. Fayolle, and D. Redford (eds), Handbook on the entrepreneurial university (pp.II2-I35). Cheltenham: Edward Elgar.

Republic of South Africa. (2007). Policy Framework for the Government- 
wide Monitoring and Evaluation System. Pretoria: The Presidency.

Robinson, L., Cotten, S.R., Ono, H., Quan-Haase, A., Mesch, G., Chen, W., Schulz, H., Hale, T.M., and Stern, M.J. (20I5). Digital inequalities and why they matter. Information, Communication and Society 18(5), 569-582.

Routley, L. (20I4). Developmental states in Africa? A review of ongoing debates and buzzwords. Development Policy Review 32(2), I59-I77.

Sandmann, L.R., Jordan, J.W., Mull, C.D., and Valentine, T. (20I4). Measuring boundary-spanning behaviors in community engagement. Journal of Higher Education Outreach and Engagement 18(3), 83-104.

Sandmann, L.R., and Kliewer, B.W. (20I2). Theoretical and applied perspectives on power: recognizing processes that undermine effective community-university partnerships. Journal of Community Engagement and Scholarship 5(2), 22-37.

Schwab, K. (2016). The fourth industrial revolution. Geneva: The World Economic Forum.

Senge, P. (I990). The fifth discipline. New York: Currency Doubleday.

Slamat, J. (20IO). Community engagement as scholarship: a response to Hall. In Community engagement in South African higher education, Kagisano, 6 (pp.Io4-II4). Pretoria: Council on Higher Education.

Strier, R. (2OII). The construction of university-community partnerships: entangled perspectives. Higher Education 62(I), 8I-97.

Strier, R. (20I4). Fields of paradox: university-community partnerships. Higher Education 68(2), I55-165.

Stromquist, N.P., and Monkman, K. (20I4). Defining globalization and assessing its implications for knowledge and education, revisited. In N.P. Stromquist, and K. Monkman (eds), Globalization and education: Integration and contestation across cultures (pp.I-2I). Maryland: Rowman \& Littlefield Education.

Subban, M., and Vyas-Doorgapersad, S. (2014). Public administration training and development in Africa: The case of the Republic of South Africa. Journal of Public Affairs Education 20(4), 499-514.

Subotzky, G., and Prinsloo, P. (20II). Turning the tide: A socio-critical model and framework for improving student success in open distance learning at the University of South Africa. Distance Education 32(2), I77-I93.

Tahar, S., and Boutellier, R. (2013). Resource allocation in higher education in the context of New Public Management. Public Management Review 15(5), 687-7II.

Tumiel-Berhalter, L, Watkins, R., and Crespo, C. J. (2005). Communitybased participatory research: Defining community stakeholders. Metropolitan Universities 16(I), 93-106.
Van Schalkwyk, F. (20I5). University engagement as interconnectedness: Indicators and insights. In N. Cloete, P. Maassen, and T. Bailey (eds), Knowledge production and contradictory functions in African higher education (pp.203-229). Cape Town: African Minds.

Vicente, M.R., and Novo, A. (20I4). An empirical analysis of e-participation. The role of social networks and e-government over citizens' online engagement. Government Information Quarterly 31(3), 379-387.

Warren, M.R., Park, S.O., and Tieken, M.C. (20I6). The formation of community-engaged scholars: A collaborative approach to doctoral training in education research. Harvard Educational Review 86(2), 233-260.

Weerts, D.J., and Sandmann, L.R. (2008). Building a two-way street: Challenges and opportunities for community engagement at research universities. The Review of Higher Education 32(I), 73-106.

Weerts, D.J., and Sandmann, L.R. (20I0). Community engagement and boundary-spanning roles at research universities. The Journal of Higher Education 81(6), 632-657.

Welch, M. (2016). Engaging higher education: Purpose, platforms, and programs for community engagement. Sterling, Virginia: Stylus Publishing, LLC.

Wiewel, W., and Knaap, G. (2005). Partnerships for smart growth: Universitycommunity collaboration for better public places. Armonk, New York: M.E. Sharp Inc.

Winberg, C. 2006. Undisciplining knowledge production: Development driven higher education in South Africa. Higher Education 51(2): I59I72.

Winter, A., Wiseman, J., and Muirhead, B. (2006). University-community engagement in Australia: Practice, policy and public good. Education, Citizenship and Social Justice 1(3), 21I-230.

Winter, R. (2009). Academic manager or managed academic? Academic identity schisms in higher education. Journal of Higher Education Policy and Management 31(2), I2I-3I.

Witter, S., Toonen, J., Meessen, B., Kagubare, J., Fritsche, G., and Vaughan, K. (20I3). Performance-based financing as a health system reform: mapping the key dimensions for monitoring and evaluation. BMC Health Services Research 13(I), 367-376.

Xing, B., and Marwala, T. (20I7). Implications of the fourth industrial age on higher education. arXiv preprint arXiv:I703.09643. Retrieved January 27, 2019, from: https://arxiv.org/ftp/arxiv/papers/1703/I703.09643. pdf

Xing, B., Marwala, L., and Marwala, T. (2018). Adopt fast, adapt quick: Adaptive approaches in the South African context. In N.W. Gleason (ed.), Higher education in the era of the fourth industrial revolution 
(pp.I7I-206). Singapore: Palgrave Macmillan.

Zomer, A., and Benneworth, P. (20II). The rise of the university's third mission. In J. Enders, H.F. de Boer, and D.F. Westerheijden (eds), Reform of higher education in Europe (pp.8I-Ior). Rotterdam: Sense Publishers.

Zwane, E. (20I4). Monitoring and evaluation mechanisms for sustainable development in Sedibeng district municipality. PhD thesis, NorthWest University, South Africa. 